\title{
First report of powdery mildew caused by Golovinomyces neosalviae on Lavandula stoechas in Italy
}

\author{
Angelo Garibaldi ${ }^{1}$ - Domenico Bertetti ${ }^{1}$. Slavica Matić ${ }^{1}$ Patrizia Martini ${ }^{2} \cdot$ Maria Lodovica Gullino $^{1}$
}

Received: 20 September 2019 / Accepted: 28 January 2020 / Published online: 3 February 2020

(C) Società Italiana di Patologia Vegetale (S.I.Pa.V.) 2020

Keywords French lavender · Ornamental plants $\cdot$ Powdery mildew

During winter and spring of 2019, several plants of Lavandula stoechas cv. Ruflex growing in a farm located in Albenga (Savona province, northern Italy) showed a whitish to greyish mycelium colonizing stems and leaves within the canopy. Conidiophores measured 124-236 × 8-15 (average: $163 \times$ 11) $\mu \mathrm{m}$ and they were variable in size and arrangement of cells. Foot-cells were erect or curved at the base, with a basal septum raising above the mother cell and measured 28-146 $\times$ $8-13$ (average: $67 \times 11) \mu \mathrm{m}$. The foot-cells were followed by 2-5 cells measuring $14-95 \times 8-15$ (average: $32 \times 11$ ) $\mu \mathrm{m}$. Conidia were lacking of fibrosin bodies, they were doliiform to limoniform, formed chains (up to 5 conidia) and measured 28-40 × 17-24 (average: $34 \times 20$ ) $\mu \mathrm{m}$, with length/width $(1 / w)$ ratio between 1.3 and 2.2. Chasmothecia were not observed. The DNA of the fungal pathogen was extracted from mycelium collected from affected tissues. The primers ITS1/ PM6 (White et al. 1990) and PM5/NLP2 (Takamatsu and Kano 2001) were used for a PCR reaction to amplify the Internal Transcribed Spacer (ITS) region and the 28S rRNA gene. Two sequences with 515 and 618 bp respectively (GenBank accession numbers MN053030 and MN749535) were obtained. The NCBI blast analysis of these sequences showed 99.22\% (511/515) and 99.68\% (616/618) homology respectively, with Golovinomyces neosalviae M. Scholler, U. Braun \& Anke Schmidt (MG386701 from Salvia officinalis). Therefore, the causal agent of the powdery mildew on L. stoechas was identified as G. neosalviae, accordingly with

Domenico Bertetti

domenico.bertetti@unito.it

1 Centre of Competence for the Innovation in the Agro-Environmental Sector (AGROINNOVA), University of Turin, Largo Paolo Braccini 2, 10095 Grugliasco, Italy

2 Istituto Regionale Floricoltura, Via Carducci 12, 18038 Sanremo, Italy the features described for this pathogen (Scholler et al. 2016). A pathogenicity test was performed by gently pressing the leaves of three plants of $L$. stoechas cv. Ruflex onto leaves of the same host affected by G. neosalviae. Three noninoculated plants were used as control. About 20 days later, first symptoms and signs of powdery mildew were observed on the inoculated plant, while controls remained symptomless. G. neosalviae was reported on Salvia officinalis, S. fruticosa and S. lavandulifolia (Scholler et al. 2016). To our knowledge this is the first report of G. neosalviae on L. stoechas in Italy, as well as worldwide.

\section{References}

Scholler M, Schmidt A, Siahaan SAS, Takamatsu S, Braun U (2016) A taxonomic and phylogenetic study of the Golovinomyces biocellatus complex (Erysiphales, Ascomycota) using asexual state morphology and rDNA sequence data. Mycol Prog 15(6):1-13

Takamatsu S, Kano Y (2001) PCR primers useful for nucleotide sequencing of rDNA of the powdery mildew fungi. Mycoscience 42:135139

White TJ, Bruns T, Lee S, Taylor JW (1990) Amplification and direct sequencing of fungal ribosomal RNA genes for phylogenetics. In: Innis MA, Gelfand DH, Sninsky JJ, White TJ (eds) PCR protocols: a guide to methods and applications. Academic Press, San Diego, pp 315-322

Publisher's note Springer Nature remains neutral with regard to jurisdictional claims in published maps and institutional affiliations. 